\title{
Research for Local Universities of Science and Technology Park Innovation Management
}

\author{
Rui TANG \\ School of Mechanical Engineering \\ Panzhihua University \\ Panzhihua, China \\ E-mail:904200315@qq.com
}

\begin{abstract}
This paper analyzed construction mode of local colleges and universities' university science park, put forward exist problems of local colleges and universities' university science park in process of construction and development and obtained the conclusion that local colleges and universities' university science park should closely combine regional economy and practical of social undertaking development, integrate all parties resource, improve core competitiveness and carry out servicing society function.
\end{abstract}

Keywords-local colleges and universities; university science park; core competitiveness

\section{INTRODUCTION}

University is one of the source of knowledge innovation and technological innovation, university science park is an important form and effective carrier to speed up the transformation of university scientific and technological achievements, an important component of national innovation system and an important platform of industry-universityresearch cooperation of universities, service of society, training of innovative entrepreneurial talent, and it provide strong supports for regional economic development and industry technology progress[1]. University science park is a science and technology industrial park, which regards university which own advantage of knowledge, talents and research \& development as support, and it stimulates science and technology enterprises or high technology companies to create and develop and promotes research \& development innovation of university science and technology, transformation of scientific research achievement, hi-tech enterprises incubation, career-creating talents cultivation and combination involving production teaching and research by providing favorable conditions such as sites, funds, policy and so on. University science park of China began in the 1980s, until the end of 2015, university science park of China had achieved more than 300 , the national university science park had achieved 115, which has become the important component of the high and new tech development zone, and it has also become the growing point of emerging industry. From the development experience of developed countries' science park, normative development of university Science Park has very important significance to enhance the research \& development level of Chinese science and technology, promote the "public innovation, peoples' innovation" and build a new engine of China economy. Therefore, we should further strengthen the policy support and system lead of university Science Park.

At present, the university science parks' construction of coastal open cities and provincial capitals has gradually matured, which has played a positive role for the local economic development, while university science parks' construction of local colleges under provincial capital is still at the exploratory stage of gradual development. Using local city Panzhihua located in the western region as an example, this city is Chinese famous three-line construction city, which is an emerging industrial city that is main strategic resources such as steel and vanadium titanium. Since the city was built in fifty years ago, Panzhihua has been based on abundant mineral resources to establish a multitude of large and medium-sized key enterprises and private enterprises and form a complete industrial system. Its rich mineral resources, solid industrial strength and numerous scientific and technical personnel provided precious opportunities for the development of Panzhihua's new industry in the new century. But, as an old industrial base, there are also questions in Panzhihua such as worse capability of independent innovation, lack of high-quality talents, weak core competitiveness and less science and technology enterprises that own large scale and good prospects. Therefore, the Panzhihua city's strategic objectives of 13th Five Year Plan is to speed up the industry adjustment, structure upgrading and strategic transformation of resource-based city and build innovation-oriented city. To achieve this goal, we must energetically adjust economic structure, change economic growth pattern cogently, exert ourselves to promote technology innovation and industry innovation, strongly promote new industrialization and urbanization and develop breakthrough high and new technology industry.

\section{LOCAL UNIVERSITY SCIENCE AND TECHNOLOGY PARK CONSTRUCTION MODE}

At present, Panzhihua has two universities which are Panzhihua University and Sichuan Electromechanical Institute of Vocation Technology, multiple scientific research institutions and vocational technical institutes. These academies have good resources of science and technology and talent advantages, their scientific research areas involve 
electronic information, mechatronics, mining and smelting, new materials, environmental protection, biomedical engineering, deep processing of agricultural products and other high and new technology fields. According to the industry status quo of panxi area and the advantage of local universities and research institutions, combining with Panzhihua city's 13th Five Year Plan and prospective goal, author thinks that the development of university science park in panxi region should give priority to Panzhihua University and use "multi-campus and one park" mode, the function of science park should be orientated: independent technology innovation base, high and new technology enterprise incubating base, innovative entrepreneurial talent training base and combination involving production teaching and research demonstration base. Panzhihua University Science Park's body is university. It needs powerful guidance and support of the local government to use "multi-campus and one park" mode. Adopts the model of "what a school garden", the use of the resource advantages of Panzhihua and investment environment, industry characteristics, universities and research institutes of talent and technology advantages, attract social diversification, focus the power of colleges and universities and research institutions, as soon as possible to make science and technology park form a larger scale, produce cluster effect, form the demonstrative leading, better serve the local economy and social development. Author thinks that Panzhihua University science park construction should gradually promote and perfect from the following aspects.

Firstly, government departments, research institutes and social resources to participate construction of university science park. The local government and universities should adopt the market economy development thinking to guide the construction of university Science Park. Through policy guidance, it can absorb social capital and risk investment, through demutualization company operation mode, it can make university science park construction and local economy development be organic combination [2]. The first point is that the government functional department should provide policy support and guide, the university science park is regarded as the important source of national high and new technology industry development, and it can cultivate a new growth point of regional economy and promote industrial structure adjustment, it can also optimize and upgrade the important means of urbanization progress. The second point is that universities should give play to their advantages of resources and technology and make full use of university social influence and brand advantage to attract potential projects, high-tech talents and risk investment into park. The third point is that social resources should be widely absorbed to participate in university Science Park, at the present, financing is difficult, channel is single, which perplex the achievements transformation and industrialization of university Science Park. The necessary science and technology risk investment and financing system of science and technology achievements transformation and industrialization is not sound, which severely restricts the construction and development of university Science Park. University Science Park should make full use of system advantage to break the capital bottleneck as a science and technology enterprise's incubation platform. University science park is close to university, hi-tech talents gather, atmosphere of research \& development and innovation is deep, there are also academic and cultural environment that other high-tech zone or industrial park lacks, if it adopt more flexible operation mechanism and create a good and loose investment environment, it will attract more and more social capital and risk investment to enter.

Secondly, integration of university science park resources advantage, promote regional economic development. The university science park, which is based on the intelligence of universities' talents and scientific research technology, is the important base of national independent innovation and the important constituent of innovation system, the important channel of transformation and industrialization of universities' scientific and technological achievements and the regional economic development and one of source of industry progress innovation. University science park can use these functions such as incubation, agglomeration and comprehensive service to promote technological progress and industrialization, cultivate a large number of innovative entrepreneurial talents and enterprise management talents, promote enterprise getting fast growth, create a large number of new jobs at the same time, increase the fiscal revenue of local government and become the engine to promote development of regional economic. Through production and education fuse and university and enterprise cooperate, good projects can be attracted into park relying on the brand advantage of university and research environment, and the local companies are responsible for the construction of infrastructure and startup capital of project, at the same time they absorb certain social funds and venture capital, promote enterprise incubation and promote development and progress of local economic undertakings. University Science Park will also attract a large number of innovative and entrepreneurial talents to come to obtain employment or startup businesses, it can promote local economic to develop and progress.

\section{UNIVERSITY SCIENCE PARK MANAGEMENT PROBLEMS THAT EXIST IN THE LOCAL COLLEGES AND UNIVERSITIES}

Chinese university Science Park has made considerable development since it was established in ten years ago, and it made outstanding contributions for the industrialization of high and new technology, but there are still gaps compared with developed countries, the biggest gap is the lack of innovation in administration. At present, Panzhihua University Science Park has achieved initial success in terms of the transformation of scientific and technological achievements and development science and technology industry. With the help of university science and technology strength, it has obtain certain development in industries such as comprehensive utilization of vanadium and titanium resources, development and application of new energy materials, biotechnology, building design, urban planning and culture creativity. The investment and financing advisory services and policy support which were provided to enterprises and project in the park provided technical support to hatch and cultivate high-tech enterprises, resident enterprises can make full use of school's scientific research 
facilities, resource sharing, and collaborative development, so as to achieve certain results. But the problems that university science park exposed don't be allowed to ignore, these problems mainly display in: the first point is the lack of scientific research's quality and quantity, the second point is the strength of policy support and financial support is insufficient, the third point is industrial docking resources are insufficient, local economy enterprise level is lower, to engage in production activities are mostly part of the chain, the demand of technical research and development and talent training is not high, enthusiasm of participation is lacking, which restricts the space of university science park's survival and development. And there are two main reasons causing these problems:

Firstly, the policy guidance is not clear. Local government has not unified support and incentive policies in terms of fiscal and tax, capital construction, talent incentivation for university science park, the relevant policies formulated by local government and supported university are still fuzzy and remain to be further refined and perfect. The current tax policies are very unfavorable for small and medium-sized science and technology enterprises. Because research and development spending and test facility aren't reckoned in cost, the enterprises whose additional value is higher pay more taxes according to the current added-value tax law. So enterprises aren't willing to increase investment generally in research and development aspect, which seriously influence the research \& development innovation degree and enterprise incubation efficiency of university Science Park.

Secondly, the institutional is constrained. From the education management system, the current college's teaching management model attach most importance to generality but personality, openness is not enough, which is not conducive to the growth of innovative entrepreneurial talents. From the personnel distribution management system, many enterprises in university science park are transformed from the intrinsic school-run enterprises, they are affected by traditional schoolrun enterprise operation, enterprises of university science park often do not have independent distribution system but refer to the distribution of school, staff salary usually cannot fully embody the principle of that recompense is made according to the amount of labour expended. Many university's incentive policy of science and technology achievements' inventor trends conservative, which cannot effectively arouse enthusiasm of entrepreneurship of the technological achievements holder. From the investment and financing system, capital exit mechanism is not perfect, so it's hard for risk Investment Company to couch more successful venture businesses' listing. There are a number of high-tech enterprise born out of university, research institute or traditional enterprise, they are fuzzy with the relationship of original unit, in addition, property rights appraisal institution and property rights trading market are not developed, these made that hightech enterprises can't freely convert property rights and hindered the channel of stock transfer.

\section{SOME ADVICE FOR THE DEVELOPMENT OF SCIENCE AND TECHNOLOGY PARK}

Our country pays high attention to the construction of national grade university science park, it gives great support from all aspects, but university science park of local universities is hard to enter into the category of national grade category, local colleges mostly belong to the head of the provincial level, its science park is mostly provincial level, it's especially hard for university science park whose possession is not provincial capital, preferential policy and funding support strength are far from enough, it in certain degree restricts the development of university science park. The construction and development of university Science Park of local universities need more combine the unique advantages of colleges and the reality of regional economic development, strengthen management of innovation, enhance core competitiveness, fulfill social service function of universities and promote development of local economy and social undertaking [3].

Firstly, it's supposed to strive that the government departments at all levels introduce corresponding policy support and standardize the construction of university science park, the local government should make the construction of university science park bring into the local global development plan, and it should introduce specific supportive measures and support the construction of university science park in terms of policy, capital, infrastructure and so on. Especially, in initial stage of the construction of university Science Park, government should set up platform construction funds of university Science Park and respectively allocate according to the results of performance evaluation of university Science Park.

Secondly, it should broaden industry-university-research cooperation channel and integrate into the local innovation system. University science park construction must insist the development principle of "government support, university leading, and market operation". when development plan of university science park is formulated, it's necessary combine the development goal of local economic construction and the characteristics of regional industrial economy environment to consider, and we should be hard to make local government science is definite for preferential policies in terms of university scientific research tax, science and technology project funds and land utilization. When the construction of university science park satisfies the need of university discipline construction, it also need to find the integrating point of school's applied science research direction and local market demand, actively support the high and new technology industries which can solve the major problems in the local production and living areas and make these projects with nonprofit nature get acceptance and financial support of local government and enterprises at the beginning of project establishment. Under the guidance and promotion of local government departments at all levels, university should integrated into the local science and technology innovation system, unite by getting married with all parties advantage of social, extensively carry out manufacture-learning-research cooperation of all kinds of fields, actively integrated into the 
local economy and become one of the important force of speeding up the construction of regional economy.

Thirdly, universities should establish transformation mechanism of achievements which faces market. When the of scientific and technological achievements transformation enterprises are established, universities should set up the concept that production factors participate in distribution and solve the question of "production factors participate in distribution" well. We need admit that developer and transformer occupy partial intellectual property and make achievement transformer owns personal technology stock. Only "personal intangible assets" get protection, the enthusiasm of continuous innovation can be improved. This is not only the need of transformation of scientific and technological achievements, but also the need of market system. At the same time, the operating management of achievement transformation need use laws and regulations to restrain, specific measures as follows: university should sign a contract with the enterprise which has enter and been stationed in university science park and determine the respective proportion of two cooperative sides. University establish reasonable and fair allocation principle of scientific and technological achievements and company stocks and tangibly ensure the vital interests of scientific and technological developers, transformers, entrepreneurs and capital owner. The departments, enterprises and technical companies of Science Park possessed independent nature implement shareholding system reform and proceed operating management according to modern enterprise institution. Besides, university can use the form of building asset management limited liability company, which not only ensures companies that university owns holding and jointstock make themselves' funding which is used to incubate use on transformation of university's scientific research achievement, but also make companies that university owns holding and joint-stock get scientific research achievements from university and keep innovation vitality. Fourthly, besides formulating strict enterprise access system, university should also be further realize diversification of financing channels, strengthen capital support functions including building project evaluation and examination and approval system that face science and technology industry plan and strive for earmarks support of all levels governments. University should widely raise social capital by supporting limited company of park with mature development listing. And university should introduce all kinds of financial institutions into park, set up loan guarantee of small and medium-sized science and technology enterprises and improve credit service enterprise of park.

\section{ACKNOWLEDGMENT}

Construction of Innovation Platform of Panzhihua University's Science and Technology Park (Item Number: 0290100545)

\section{REFERENCES}

[1] Jin-xia Zhao, yong-shun li, Peng loose. "The significance of university science park to the local economy development," Journal of China university of science and technology, vol. 23, pp. 74-75, November 2013.

[2] Qiu wei. "Local university science park development mode for college of zhaoqing university science park - for example," Journal of knowledge library, vol. 4, pp. 20-21, April 2015.

[3] Huwen, "Yan Yun. Local colleges industry-university-institute cooperation development countermeasures study," Journal of hubei college of engineering, vol. 36, pp. 77-80, July 2016. 